\title{
Synthesis of antibodies, including antiviral antibodies in the knee joints of patients with arthritis
}

\author{
C A MIMS, ${ }^{1}$ A STOKES, ${ }^{1}$ AND R GRAHAME \\ From the 'Department of Microbiology, Guy's Hospital Medical School, and the ${ }^{2}$ Department \\ Rheumatology, Guy's Hospital, London
}

SUMMARY Serum and synovial fluids from 16 patients with seronegative arthritis and eight wit rheumatoid arthritis were studied for immunoglobulin levels and for antibody levels to five viruses. When allowances were made for the distribution of immunoglobulins between serum and synovial fluid there was evidence that in several patients antibody to one or more viruses was synthesised locally in the joint. IgG and especially IgM were present in greatly increased amount $\$$ in arthritic joints compared with normal joints. On the basis of serum/synovial fluid ratiog inflammation and local immunoglobulin synthesis are discussed as possible causes. These results are compared with antiviral antibody and immunoglobulin ratios observed in the serum an cerebrospinal fluid of patients with multiple sclerosis.

Key words: chronic arthritis, synovial fluid, rubella.

In the normal knee joint examined at autopsy the concentration of gammaglobulin in synovial fluid is about one quarter, and of albumin about a half, of that in serum. ${ }^{1}$ Gammaglobulin concentrations in synovial fluid are raised in osteoarthritis and in traumatic arthritis, but more dramatic increases are seen in rheumatoid arthritis (RA) ${ }^{1-3}$ Synovial fluid albumin is also increased and reaches similar levels in these types of arthritis.

Mononuclear cells in the rheumatoid synovium produce antibody in vitro, ${ }^{4-6}$ and by infusing radiolabelled albumin and IgG into patients Sliwinski and Zvaffler ${ }^{7}$ showed that IgG is synthesised in the joint in vivo. These authors calculated that in patients with RA 5-95 mg IgG was produced in each knee joint per day. The specificity of the IgG produced is not known, though there is a report that oligoclonal antibody to measles virus is synthesised by rheumatoid synovium in vitro, ${ }^{8}$ and in another study rubella antibody was secreted spontaneously in vitro by synovial cells from seven of 10 patients with RA. ${ }^{9}$

In the work reported here antibody titres to five different viruses were determined in joint fluids and sera of patients with seronegative arthritis and

Accepted for publication 18 April 1985

Correspondence to Professor C A Mims, Department of Microbiology, Guy's Hospital Medical School, London Bridge SE1 9RT. rheumatoid arthritis. Immunoglobulin (Ig) albumin levels were also measured to provide information as to the state of the blood-joint barrier

\section{Patients and methods}

PAT I ENTS

Twenty-four patients were studied: eight with $\mathrm{R} \stackrel{\mathrm{P}}{\mathrm{S}}$ and 16 with seronegative arthritis.

ANTIVIRAL ANTIBODIES

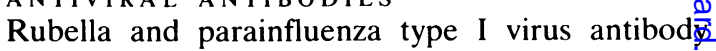
titres were determined by haemagglutination inhib tion. The rubella antigen was a BHK-21 ceff. preparation (from Wellcome Diagnostics, Beck@̊ enham, Kent) and parainfluenza I an allantoic fluił preparation. Cytomegalovirus (CMV) and respira tory syncytial virus (RSV) antibodies were titrated by fluorescent antibody staining of infected MRC and Vero cells, respectively. The anticomplement method was used for CMV (conjugate from Behring Diagnostic Reagents) and antihuman IgG staining for RSV (conjugate from Wellcome Diagnosticsw Beckenham, Kent). Antibodies to herpes simple virus (HSV) were titrated by an enzyme-linked immunosorbent assay, with an infected Vero ce preparation (Flow Laboratories, Ayrshire, Scof? land) and horse-radish peroxidase-conjugated antiv human IgG (Dako, Mercia Brocades, Surrey, UK $\vec{P}$ End points were taken as the final twofold serurg 
dilution giving an optical density reading at least $0 \cdot 2$ higher than the control value.

IMMUNOGLOBULIN AND ALBUMIN
DETERMINATION

$\operatorname{IgG}, \operatorname{IgM}, \operatorname{Ig} A$, and albumin were determined in immunodiffusion plates obtained from Boehringer Corporation, London. Concentrations in $\mathrm{mg} / \mathrm{dl}$ were read off from a reference curve constructed from standard samples supplied by the manufacturers, relating concentration to the diameter of precipitin lines.

\section{Results}

The ratios of antiviral antibody titres in serum compared with synovial fluid (SF) are shown in Table 1. Titres in SF are sometimes as high or higher than in serum, and in a given patient the picture is different for different viruses.

When the state of the blood-joint barrier is taken into account, as indicated by the ratio of total Ig (or IgG when relevant) in serum compared with SF, it is clear that antibodies to certain viruses show higher titres in SF relative to sera, than can be attributed to the concentration of immunoglobulins in SF relative

Table 1 Serum/synovial fluid antiviral antibody titre ratios in patients with chronic arthritis

$\begin{array}{llll}\text { Patient Rubella RSV CMV HSV } & \begin{array}{l}\text { Parainfluenza Serum/ } \\ \text { type I virus SF Ig* }\end{array}\end{array}$

\section{Seronegative}

$\begin{array}{ll}0.5 & 1 \cdot 0 \\ 0 \cdot 5 & 1 \cdot 0 \\ 0 \cdot 5 & 3 \cdot 0 \\ 0 \cdot 5 & 1 \cdot 0 \\ 1 \cdot 0 & 1 \cdot 0 \\ 0 \cdot 5 & 2 \cdot 0 \\ 2 \cdot 0 & 2 \cdot 0 \\ 1 \cdot 0 & 0 \cdot 75 \\ 2 \cdot 0 & 4 \cdot 0 \\ 4 \cdot 0 & 2 \cdot 0 \\ 1 \cdot 5 & 2 \cdot 0 \\ 6 \cdot 0 & 2 \cdot 0 \\ 1 \cdot 0 & 1 \cdot 0 \\ 4 \cdot 0 & 2 \cdot 0 \\ 2 \cdot 0 & 2 \cdot 0 \\ 2 \cdot 0 & 0\end{array}$

0
0
$2 \cdot 0$
0
0
0
$2 \cdot 0$
$1 \cdot 0$
$3 \cdot 0$
$8 \cdot 0$
-
$3 \cdot 0$
0
-0
0

$\begin{array}{ll}4 \cdot 0 & 2 \cdot 0 \\ 1 \cdot 0 & 0 \cdot 75 \\ 8 \cdot 0 & 0 \cdot 5 \\ 0 \cdot 75 & 2 \cdot 0 \\ 0 \cdot 5 & 2 \cdot 0 \\ 2 \cdot 0 & 1 \cdot 0 \\ 1 \cdot 0 & 2 \cdot 0 \\ 1 \cdot 0 & 2 \cdot 0 \\ 4 \cdot 0 & 2 \cdot 0 \\ 8 \cdot 0 & 3 \cdot 0 \\ 0 & 2 \cdot 0 \\ 4 \cdot 0 & 4 \cdot 0 \\ 0 & 2 \cdot 0 \\ 2 \cdot 0 & 8 \cdot 0 \\ 2 \cdot 0 & 4 \cdot 0 \\ 2 \cdot 0 & 4 \cdot 0\end{array}$

$R A$ (Seropositive)

\begin{tabular}{lllllll}
17 & $2 \cdot 0$ & $2 \cdot 0$ & 0 & $1 \cdot 0$ & $1 \cdot 0$ & $1 \cdot 2$ \\
18 & $4 \cdot 0$ & $2 \cdot 0$ & - & $2 \cdot 0$ & - & $1 \cdot 2$ \\
19 & 0 & $1 \cdot 0$ & $2 \cdot 0$ & 0 & $2 \cdot 0$ & $1 \cdot 8$ \\
20 & $2 \cdot 0$ & $1 \cdot 0$ & $1 \cdot 0$ & $4 \cdot 0$ & $2 \cdot 0$ & $3 \cdot 2$ \\
21 & $4 \cdot 0$ & $1 \cdot 0$ & - & $4 \cdot 0$ & $1 \cdot 0$ & $1 \cdot 1$ \\
22 & $2 \cdot 0$ & $1 \cdot 0$ & $2 \cdot 0$ & $2 \cdot 0$ & $1 \cdot 0$ & $3 \cdot 7$ \\
23 & $1 \cdot 0$ & $1 \cdot 0$ & 0 & 0 & $8 \cdot 0$ & $1 \cdot 3$ \\
24 & $2 \cdot 0$ & $1 \cdot 0$ & - & $4 \cdot 0$ & $8 \cdot 0$ & $2 \cdot 3$ \\
\hline
\end{tabular}

\footnotetext{
* Total $\operatorname{IgG}+\operatorname{IgM}+\operatorname{IgA}$. Normal value $=4 \cdot 0 .^{1}$ $0=$ no antibody detected in serum or synovial fluid; $-=$ no antibody detected in synovial fluid.
}

Table 2 Serum/synovial fluid ratios of albumin and immunoglobulins in patients with chronic arthritis

\begin{tabular}{|c|c|c|c|c|}
\hline Patient & $\begin{array}{l}\text { Serum/ } \\
\text { SF IgG }\end{array}$ & $\begin{array}{l}\text { Serum/ } \\
\text { SF IgM }\end{array}$ & $\begin{array}{l}\text { Serum/ } \\
\text { SF } \operatorname{Ig} A\end{array}$ & $\begin{array}{l}\text { Seru } \\
\text { SF a }\end{array}$ \\
\hline \multicolumn{5}{|c|}{ Seronegative } \\
\hline 1 & 1.8 & $3 \cdot 5$ & 1.6 & $2 \cdot 2$ \\
\hline 2 & 1.9 & $24 \cdot 0$ & $3 \cdot 8$ & 1.9 \\
\hline 3 & 0.9 & 1.0 & 1.0 & $1 \cdot 0$ \\
\hline 4 & $2 \cdot 5$ & $3 \cdot 5$ & $4 \cdot 7$ & $1 \cdot 3$ \\
\hline 5 & $0 \cdot 8$ & $1 \cdot 0$ & $1 \cdot 3$ & $1 \cdot 2$ \\
\hline 6 & 0.9 & 1.8 & $2 \cdot 0$ & $1 \cdot 2$ \\
\hline 7 & 1.5 & $2 \cdot 7$ & 1.7 & $1 \cdot 3$ \\
\hline 8 & 1.9 & 0.7 & $3 \cdot 0$ & $1 \cdot 1$ \\
\hline 9 & $3 \cdot 2$ & $32 \cdot 5$ & $4 \cdot 6$ & 1.9 \\
\hline 10 & $7 \cdot 7$ & $8 \cdot 2$ & $15 \cdot 9$ & $2 \cdot 4$ \\
\hline 11 & $6 \cdot 0$ & $4 \cdot 1$ & $2 \cdot 7$ & $2 \cdot 1$ \\
\hline 12 & 1.9 & $2 \cdot 5$ & $3 \cdot 3$ & $2 \cdot 6$ \\
\hline 13 & $1 \cdot 3$ & $1 \cdot 2$ & $2 \cdot 0$ & $1 \cdot 3$ \\
\hline 14 & $2 \cdot 8$ & $2 \cdot 4$ & $2 \cdot 6$ & $2 \cdot 7$ \\
\hline 15 & $2 \cdot 0$ & $2 \cdot 5$ & $2 \cdot 6$ & 0.8 \\
\hline 16 & 0.9 & $1 \cdot 0$ & 1.2 & $2 \cdot 3$ \\
\hline
\end{tabular}

\section{$R A$ (seropositive)}

\begin{tabular}{lllll}
17 & $1 \cdot 1$ & $1 \cdot 8$ & $3 \cdot 9$ & $1 \cdot 2$ \\
18 & $1 \cdot 0$ & $1 \cdot 1$ & $3 \cdot 0$ & $1 \cdot 0$ \\
19 & $1 \cdot 5$ & $5 \cdot 5$ & $2 \cdot 3$ & $1 \cdot 5$ \\
20 & $3 \cdot 6$ & $2 \cdot 4$ & $2 \cdot 8$ & $2 \cdot 0$ \\
21 & $1 \cdot 1$ & $4 \cdot 7$ & $0 \cdot 4$ & $1 \cdot 5$ \\
22 & $4 \cdot 4$ & $3 \cdot 8$ & $2 \cdot 6$ & $1 \cdot 9$ \\
23 & 0.9 & $3 \cdot 5$ & $5 \cdot 8$ & $1 \cdot 0$ \\
24 & $2 \cdot 3$ & $7 \cdot 6$ & 1.9 & 1.9 \\
Normal* $^{*}$ & $7 \cdot 7$ & $22 \cdot 2$ & & 1.9 \\
\hline
\end{tabular}

${ }^{*}$ See references 1 and 3 .

to sera. All antibody titrations were carried out with twofold dilutions of serum, and it was found that titres did not differ by more than twofold on retesting given specimens, so that fourfold or greater differences in ratio compared with the ratios of total IgG are likely to be significant. When these ratios were found for a given virus the antibody titrations were repeated, mean values were used in calculations, and fourfold or greater differences in ratios assumed to be probably significant. For example the SF of patients No 4 and probably No 2 have lower ratios of titres to rubella virus, and patient No 22 to RSV, than can be explained by the total Ig or the IgG in SF compared with serum (Table 2). On the other hand, in patients Nos 5, 6, and $7 \mathrm{SF}$ antibody titres to all viruses are as might be expected from the total amount of $\mathrm{Ig}$ in the SF.

Serum/SF ratios for the different Ig classes and for albumin are shown in Table 2, and the values for normal patients whose SF was obtained at autopsy ${ }^{13}$ are also indicated. It can be seen that although ratios for albumin in the arthritic patients studied here are similar or slightly reduced compared with those in normal joints, the ratios for IgG, 
Table 3 Summarised results for albumin, $\operatorname{Ig} G, \operatorname{Ig} M$, and $\operatorname{Ig} A$ in serum and synovial fluids of patients with chroni€ arthritis

\begin{tabular}{|c|c|c|c|c|c|c|c|c|c|c|c|c|}
\hline & \multicolumn{3}{|c|}{ Albumin } & \multicolumn{3}{|l|}{$\operatorname{Ig} G$} & \multicolumn{3}{|l|}{$\lg M$} & \multicolumn{3}{|l|}{$\operatorname{Ig} A$} \\
\hline & Serum & $S F$ & $\begin{array}{l}\text { Serum/ } \\
\text { SF ratio }\end{array}$ & Serum & $S F$ & $\begin{array}{l}\text { Serum/ } \\
\text { SF ratio }\end{array}$ & Serum & $S F$ & $\begin{array}{l}\text { Serum/ } \\
\text { SF ratio }\end{array}$ & Serum & $S F$ & $\begin{array}{l}\text { Serum/ } \\
\text { SF ratio }\end{array}$ \\
\hline RA group* & 2397 & 1712 & $1 \cdot 40$ & 1105 & 806 & $1 \cdot 37$ & 141 & 47 & $3 \cdot 00$ & 270 & 118 & $2 \cdot 29$ \\
\hline Seronegative group ${ }^{\dagger}$ & 3312 & 2124 & $1 \cdot 56$ & 1331 & 830 & $1 \cdot 60$ & 176 & 82 & $2 \cdot 15$ & 301 & 136 & $2 \cdot 21$ \\
\hline
\end{tabular}

${ }^{*}$ Mean values in $\mathrm{mg} / \mathrm{dl}$. $(\mathrm{mg} / \mathrm{dl} \times 10=\mathrm{mg} / \mathrm{l}$. $)$

†Decker et al. ${ }^{\prime}$

$\ddagger$ Kushner and Somerville. ${ }^{3}$

IgM, and total Ig (Table 1) are often reduced. This indicates that albumin passes into SF with similar facility in arthritic and normal joints, but $\operatorname{IgG}$ and IgM are often greatly increased in the arthritic joint compared with the normal joint. This could reflect increased passage of larger molecules into the SF of inflamed joints or alternatively the synthesis of immunoglobulin in the joint. Thus in the case of patients Nos 2 and 9 the reduced IgG but normal IgM ratios show that either the inflammation was not severe enough to allow the larger IgM molecules to pass into the SF or that IgM was not synthesised in the joint. The results are summarised in Table 3. In the RA patients studied the mean serum/SF ratio for $\operatorname{IgG}$ was 1.37 compared with 1.60 in the seronegative group. Statistical analysis using Student's $t$ test showed that this was not significant $(\mathrm{p}<0 \cdot 8)$. For IgM the mean serum/SF ratio was higher in RA (3.00) than in the seronegative group $(2 \cdot 15)$, but this also was not significant $(\mathrm{p}<0 \cdot 3)$. For IgA the mean values in RA patients were 118 (SF) and $270 \mathrm{mg} / \mathrm{dl}$ (serum), but these are not significantly lower $(p<0.5)$ than the values of $136(S F)$ and $301 \mathrm{mg} / \mathrm{dl}$ (serum) in seronegative patients. In both groups of patients serum levels for IgG, IgM, and IgA fell within the normal range.

\section{Discussion}

The Ig and albumin results confirm previous reports and reflect inflammatory events in the joints studied, and also local synthesis of Ig. Thus both groups show a decrease in serum/SF ratios for $\mathrm{IgG}$ and a larger decrease for IgM. There was, however, no significant difference between the RA and seronegative patients in the $\operatorname{IgG}, \operatorname{IgM}$, or $\operatorname{IgA}$ serum/SF ratios. There is much evidence for antibody synthesis in the joints of patients with RA. ${ }^{4} 7$ Plasma cells synthesising rheumatoid factor are also know to be present in joints of patients with RA, 1011 and serum/SF ratios for rheumatoid factor indicate synthesis of rheumatoid factor in joints. ${ }^{12}$
The results obtained here are consistent with locat IgG and especially IgM synthesis in the joints of both groups of patients. In the case of $\operatorname{IgA}$ there are no values for normal joints, but the two groups of patients show no significant difference in serum $/ \mathrm{SF}$ ratio.

The antiviral antibody results suggest that anti $\vec{z}$ bodies to certain viruses but not others are synthe울 sised in the joints of patients with arthritis, since serum/SF ratios sometimes diverge significantly from the ratios for total $\mathrm{Ig}$. As in the case of antibodies synthesised intrathecally in patients who multiple sclerosis the question arises whether thispor (a) reflects the presence of antigen in the joint; $(b \bar{\Phi}$ i due to polyclonal activation of B cells; or $(c)$ is a result of random trapping of plasmablasts in the joint.

So far, with the exception of reports about⿱亠䒑 rubella, ${ }^{13-18}$ there has been a shortage of reliable repeatable evidence for the presence of viruses of viral antigens in the joints of patients with arthritis Even in the dramatic polyarthritis occurring during infection with the mosquito-transmitted Ross Rive virus in Australia there is so far no evidence for virus or viral antigen in affected joints. ${ }^{19}$ Cremer et al. ${ }^{28}$ found that cryoprecipitates (immune complexes from synovial fluids of patients with RA containe 8 antibodies to certain viruses. The viruses concerned (herpes simplex and respiratory syncytial virus 9 were generally those with the highest serum anti body titres, and it seems likely that the antivira? antibody was complexed with rheumatoid factor Polyclonal activation of $B$ cells is an acceptedP phenomenon, for instance in acute Epstein-Barf virus infections, and has been described in peri స్ట pheral blood cells and synovial fluid cells in patients with seropostive RA. ${ }^{\circ}$ Finally, there is the possi $i_{0}$ bility that circulating plasmablasts are randomly trapped in inflamed joints, and, freed from immunos regulatory control, differentiate to secrete theiro specific antibody. Circulating plasmablasts might beo more likely to have specificity for common infect $\widehat{\Omega}$ 
ious agents such as the viruses studied here. Antibody to measles ${ }^{8}$ or rubella ${ }^{9}$ is spontaneously synthesised in vitro by synovial or synovial fluid cells from patients with RA. Recent infection, reinfection, or persistent infection with these viruses could lead to the appearance of occasional plasmablasts in the circulation. Very similar considerations have been used to explain the intrathecal synthesis of antiviral antibodies in multiple sclerosis. ${ }^{21}$ Antibodies against up to 11 common viruses and also against mycoplasmas or tetanus toxin can be synthesised in the central nervous system of a given patient. If this explanation also applies to the joints of patients with RA and to many with seronegative arthritis, it explains the antiviral antibody results without in any way suggesting that viruses or viral antigens are directly involved in the disease.

Degre et al. ${ }^{22}$ found immune interferon in SF and in the serum of patients with RA, and the SF/serum ratios of interferon compared with total protein suggested that in a least one patient the joint was the source of the interferon. Synthesis of immune interferon by cells in joints may reflect immunoregulatory phenomena rather than infection.

\section{Addendum}

Synovial fluid from eight of the seronegative patients studied in this report had on occasions shown interference with the growth of ECHO II virus in African green monkey kidney cells. This was initially thought to be due to rubella virus. In further (unpublished) studies the interference was also at times demonstrable in their serum samples and appears to be due to ECHO II virus neutralising antibody present in synovial fluid and serum. The antibody is incompletely removed by a single medium change - interference was not observed when monkey kidney cells were thoroughly washed five hours after addition of test fluids. The interference is not due to interferon, in so far as interferon was not demonstrable in a sensitive assay using Semliki Forest virus, and interference was inhibited neither by bovine antibody to alpha and beta interferon (kindly supplied by $\mathrm{Dr} \mathrm{K}$ H Fantes, Wellcome Research Laboratories, Beckenham, Kent) nor by heating test fluids at $56^{\circ} \mathrm{C}$ for 30 minutes. The interfering material did not appear to be rubella virus since it was not sedimentable by centrifugation at $100000 \mathrm{~g}$ for one hour, not affected by neutralising antibody to rubella virus, and not affected by heating at $56^{\circ} \mathrm{C}$ for 30 minutes. We were thus not able to confirm the isolations of rubella virus reported in previous papers. ${ }^{23} 24$

This work was supported by a grant from the Arthritis and Rheumatism Council.

\section{References}

1 Decker B, McKenzie B F, McGuckin W F, Slocumb C H. Comparative distribution of proteins and glycoproteins of serum and synovial fluid. Arthritis Rheum 1959; 2: 162-77.

2 Wilkinson J. Jones B S. Serum and synovial fluid proteins in arthritis. Ann Rheum Dis 1962; 21: 51-8.

3 Kushner I, Somerville J A. Permeability of human synovial membrane to plasma proteins. Arthritis Rheum 1971; 14: $560-70$.

4 Herman J H. Bradley J, Smiley J. D. Capacity of the rheumatoid synovial membrane to respond to systemic immunization. Arthritis Rheum 1958; 11: 825.

5 Smiley J D. Hoffman W L. Protein synthesis in rheumatoid synovial tissue. Springer Semin Immunopathol 1981; 4: 103-23.

6 Al-Balaghi S, Strom H, Moller E. High incidence of spontaneous IgG-producing lymphocytes in peripheral blood and synovial fluid of patients with active seropositive rheumatoid arthritis Scand J Immunol 1982; 16: 69-76.

7 Sliwinski A J, Zvaffler N J. In vivo synthesis of IgG by rheumatoid synovium. J Lab Clin Med 1970; 76: 304-10.

8 Vandvik B, Mellbye J O, Norrby E. Local synovial synthesis of oligoclonal measles virus antibodies and of smooth muscle antibodies in a case of antigenical rheumatoid arthritis. Ann Rheum Dis 1977; 36: 302-10.

9 Chattopadhyay H, Chattopadhyay C, Natvig J B, Wiger D. Mellbye $O J$. Demonstration of anti-rubella antibody secreting cells in RA patients. Scand J Immunol 1979; 10: 47-54.

10 Munthe E, Natvig J B. Immunoglobulin classes, subclasses and complexes of IgG rheumatoid factor in rheumatoid plasma cells. Clin Exp Immunol 1972; 12: 55-70.

11 Vaughan J H, Chihara T, Moore T L, et al. Rheumatoid factor producing cells detected by direct haemolytic plaque assay. $J$ Clin Invest 1976; 58: 933-41.

12 Jones V E, Jacoby R K. Cowley P J, Warren C. Immune complexes in early arthritis. II Immune complex constituents are synthesized in the synovium before rheumatoid factors. Clin Exp Immunol 1982; 49: 31-40.

13 Hildebrandt H M, Maassab H F. Rubella synovitis in a one year old patient. $N$ Engl J Med 1966: 274: 1428-30.

14 Wiebel R E, Stokes J, Baynak E B. Hilleman M R. Rubella vaccination in adult females. $N$ Engl $J$ Med 1969; 280: 682-5.

15 Ogra P L. Herd J K. Arthritis associated with induced rubella infection. J Immunol 1971: 107: 810-3.

16 Ogra P L, Chiba Y, Ogra S S, Dsurba J L, Herd, J K. Rubella virus infection in juvenile rheumatoid arthritis. Lancet 1975; i: 1157-61.

17 Fraser J R E, Cunningham A L. Hayes K, Leach R, Lunt R. Rubella arthritis in adults. Isolation of virus. cytology and other aspects of infection. Clin Exp Rheumatol 1983; 1: 287.

18 Chantler J K. Tingle A J, Petty R E. Persistent rubella virus infection associated with chronic arthritis in children. $N$ Engl $J$ Med (in press).

19 Hazelton R A, Aaskov J G. The inflammatory response in the synovium of a patient with Ross River arbovirus infection. Aust NZ J Med 1985; 15(suppl): 188.

20 Cremer N E, Hurwitz D, Quismorio F P, Lennet E H, Friou G J. Antiviral antibodies in rheumatoid synovial fluid and cryoprecipitates. Clin Exp Immunol 1974; 18: 27-37.

21 Salmi A, Reunanen M. Ilonen J, Panelius M. Intrathecal antibody synthesis to virus antigens in multiple sclerosis. Clin Exp Immunol 1983; 52: 241-9.

22 Degre M, Mellbye O J, Clarke-Jenssen O. Immune interferon in serum and synovial fluid in rheumatoid arthritis and related disorders. Ann Rheum Dis 1983; 42: 672-6.

23 Grahame R, Armstrong R, Simmons N A, Mims C A. Wilton J M A, Laurent $R$. Isolation of rubella virus from synovial fluid in five cases of seronegative arthritis. Lancet 1981; ii: 649-53.

24 Grahame R, Armstrong R. Simmons N A, et al. Chronic arthritis associated with the presence of intrasynovial rubella virus. Ann Rheum Dis 1983; 42: 2-13. 